\title{
Effects of Brief Anaerobic Exposures on Carbon Dioxide Production and Quality of Harvested
} Asparagus

\author{
Ana Victoria Torres-Penaranda ${ }^{1}$ and Mikal E. Saltveit \\ Mann Laboratory, Department of Vegetable Crops, University of California, Davis, CA 95616-8631
}

\begin{abstract}
Additional index words. Asparagus officinalis, controlled atmosphere, modified atmosphere, precooling, taste panel
Abstract. Freshly harvested asparagus (Asparagus officinalis L.) spears were exposed to an anaerobic $\mathbf{N}_{2}$ atmosphere for $0,2,4$, or 6 hours at 2.5 or $20 \mathrm{C}$ and then returned to 2.5C. Carbon dioxide production was measured each day, starting 3 days before and ending 11 days after the treatment. Significant increases in $\mathrm{CO}_{2}$ production relative to 0-hour controls were found within 1 day of treatment at $20 \mathrm{C}$ and were directly proportional to the duration of the anaerobic exposure. At $2.5 \mathrm{C}, \mathrm{CO}_{2}$ production relative to the 0 -hour control was stimulated by the 2 - and 4-hour treatments and depressed by the 6-hour treatment, with the relative rate of production inversely proportional to the duration of the anaerobic treatment. A decrease in $\mathrm{CO}_{2}$ production occurred 7 days after $\mathrm{N}_{2}$ treatment, regardless of temperature. A sensory panel evaluated effects of treatments on appearance quality 7 and 15 days after treatment and on taste quality 4 days after treatment. Judges could not detect any significant differences between anaerobic treatments and control. No significant difference was found in the percent of decayed asparagus among treatments as detected by visual evaluation 6 days after treatment. It appears that exposure to an anaerobic $\mathrm{N}_{2}$ atmosphere for up to 6 hours was not detrimental to the storability or quality of harvested asparagus spears. These results indicate that cooling with vaporized liquid $\mathrm{N}_{2}$, during which an anaerobic atmosphere could be produced before the spears were significantly cooled, would not reduce subsequent quality or storability.
\end{abstract}

Asparagus (Asparagus officinalis L.) is one of the most valuable and appetizing vegetables, but also one of the most perishable because of its active metabolism as reflected by its high respiration rate which ranges from 15 to $325 \mathrm{ml} \mathrm{CO} /(\mathrm{kg}$ per h) at 0 to $30 \mathrm{C}$, respectively (Lipton, 1957). Holding harvested asparagus for even a few hours at field temperatures results in considerable quality loss (King et al., 1988b; Lipton, 1957; Lutz, 1938; Platenius, 1942). Toughening is a major cause of quality loss and occurs because of a progressive increase in fibrous material starting from the base of the spear. The rate at which toughening occurs is temperature dependent. The length of the tender portion decreased 11 times more rapidly during storage at $30 \mathrm{C}$ than at $0 \mathrm{C}$ (Lipton, 1957), while the shear force required to cut spears was 2.6 times greater for spears after storage at $27 \mathrm{C}$ than at $16 \mathrm{C}$ (Clore et al., 1976). Losses of carbohydrates, protein, and amino acids have also been reported to be accentuated at elevated temperatures (Saltveit and Kasmire, 1985).

Harvested spears should be cooled quickly to minimize the occurrence of bacterial soft rot, yellowing, longitudinal depression, opening of the tips, wilting, and development of undesirable odors and flavors (Lipton, 1990). Storage temperatures near 0C are recommended for holding periods of $<10$ days. When the holding period exceeds 10 days, the optimum storage temperature is $\approx 2.5 \mathrm{C}$ because chilling injury occurs at $0 \mathrm{C}$ and the rate of deterioration is the same at 0 and $5 \mathrm{C}$.

The value of precooling (i.e., the removal of field heat as soon as possible after harvest) for extending shelf life of asparagus has been extensively analyzed (Pentzer et al., 1936; Scott and Kramer, 1949). Sharma and Wolfe (1976) developed a postharvest texture prediction model based on temperature and time of holding. They showed that from $36 \%$ to $50 \%$ of the spear mass would be

Received for publication 19 Jan. 1993. Accepted for publication 3 June 1993. The cost of publishing this paper was defrayed in part by the payment of page charges. Under postal regulations, this paper therefore must be hereby marked advertisement solely to indicate this fact.

${ }^{1}$ Present address: Calle 9 Avenidas 5 y 7, Alajuela, Costa Rica. excessively tough if held $5 \mathrm{~h}$ after harvest at 5 to $25 \mathrm{C}$, respectively. Lill (1980) showed that asparagus that was not cooled until $24 \mathrm{~h}$ after harvest became unsalable in 7 days, while rapidly cooled spears remained marketable an additional 2 days. King et al. (1988a) found that shelf life was negatively correlated with the accumulated heat units between harvest and cooling.

Since field precooling equipment is expensive, especially for small producers who would use the equipment for only a few months during the year, alternative cooling systems could be useful. Saltveit and Ballinger (1983a, b) evaluated the use of vaporized liquid $\mathrm{N}_{2}$ and $\mathrm{CO}_{2}$ for precooling blueberries and grapes. They found that the quality of blueberries was unaffected by exposure at 0 to $30 \mathrm{C}$ to a $\mathrm{N}_{2}$ or $\mathrm{CO}_{2}$ atmosphere for up to $4 \mathrm{~h}$. However, $22 \mathrm{~h}$ in a $\mathrm{CO}_{2}$ atmosphere at either 0 or $30 \mathrm{C}$ reduced fruit quality. Ke and Kader (1989) showed that stone fruits, pears, blueberries, and strawberries tolerate $\mathrm{O}_{2}$ levels between $0.25 \%$ and $1 \%$ for up to 10 days at 0 to 5C. Gariepy et al. (1991) found that precooling asparagus with vaporized dry ice $\left(\right.$ solid $\left.\mathrm{CO}_{2}\right)$ was as effective as forced air or hydrocooling in reducing storage losses. The use of such methods would result in the rapid substitution of air by the gaseous $\mathrm{N}_{2}$ or $\mathrm{CO}_{2}$ and the potential establishment of an anaerobic atmosphere. Purging controlled atmosphere rooms with vaporized liquid $\mathrm{N}_{2}$ is a commercial practice to establish low- $\mathrm{O}_{2}$ storage atmospheres for apples.

The effects of short-term exposures to anaerobic atmospheres on the subsequent sensory quality of fruits and vegetables have received inadequate attention. Ke et al. (1991) reported that a trained taste panel detected slight off-flavors in strawberries kept in $0.0 \%$ or $0.25 \% \mathrm{O}_{2}$, while $0.5 \%$ or $1.0 \% \mathrm{O}_{2}$ did not significantly effect flavor. Respiration was essentially unaffected by $0.5 \% \mathrm{O}_{2}$ at temperatures <15C. Santamaria and Simon, as mentioned by Lipton (1990), conducted formal flavor evaluations on asparagus spears held in film packages in which $\mathrm{O}_{2}$ decreased to $2 \%$ and $\mathrm{CO}_{2}$ increased to $15 \%$. Spears held under those conditions for up to 9 days at $2 \mathrm{C}$ were similar in flavor to spears held in air. In other research, marketlife was reduced by almost half when spears were held in film packages that allowed development of atmospheres as 
low as $2 \% \mathrm{O}_{2}$ and as high as $25 \% \mathrm{CO}_{2}$ in $40 \mathrm{~h}$ (Baxter and Waters, 1991).

The purpose of our research was to determine whether anaerobic $\mathrm{N}_{2}$ atmospheres had a detrimental or beneficial effect on the quality of harvested asparagus. This was done by measuring the rate of $\mathrm{CO}_{2}$ production by spears subjected to various periods of anaerobiosis and by evaluating the quality of the spears after storage. Elevated respiration rates induced by anaerbiosis could increase the rate of quality loss during storage. Quality evaluation focused on sensory measurements such as taste and appearance because of the importance of these characteristics on marketability. These factors were also evaluated because there is little data available to provide quantitative information on how appearance and taste quality are affected by storage under anaerobic atmospheres.

\section{Materials and Methods}

Materials and handling. Asparagus from the Delta Region near Sacramento, Calif., was obtained from a local wholesaler the day after harvest. The spears had been cooled to $2 \mathrm{C}$ within $4 \mathrm{~h}$ of harvest and were transported in a refrigerated container to the Univ. of California Mann Laboratory, where they were stored at 2.5C. Spears were trimmed to $20 \mathrm{~cm}$ and sorted into groups of U.S. No. 1 and No. 2 (U.S. Dept. of Agriculture, 1972). The selected spears were then washed and cooled by immersion for $10 \mathrm{~min}$ in a bath of chlorinated ice water $(130 \mathrm{mg} / \mathrm{l}$ available chlorine). Spears were drained at $2.5 \mathrm{C}$ and samples of $350 \pm 25 \mathrm{~g}$ were selected at random from each of the two quality categories. The number of spears in the samples from each category was proportional to the initial number of No. 1 and No. 2 spears. Samples were put into 4liter glass jars ventilated with a $2.5 \pm 0.5$ liters/hour flow of humidified air, which kept the $\mathrm{CO}_{2}$ concentration below $0.2 \%$. Three to five replicates of each time/temperature combination were used in each experiment.

Measurements of $\mathrm{CO}_{2}$ production and $\mathrm{O}_{2}$ concentration. The rate of $\mathrm{CO}_{2}$ production was calculated from daily $\mathrm{CO}_{2}$ measurements taken from two days before application of the $\mathrm{N}_{2}$ treatments on day 0 to 11 days after treatment, for a total of 14 days. Gas samples were taken with 1-ml plastic syringes from the inlet and outlet gas flows and were analyzed for $\mathrm{CO}_{2}$ and $\mathrm{O}_{2}$ as previously described (Saltveit and Strike, 1989).

Nitrogen treatment. Compressed $\mathrm{N}_{2}$ at $2.5 \mathrm{C}$ was introduced into the 4-liter jars through flow boards for periods of 2, 4, or $6 \mathrm{~h}$. Flow rates of $\approx 150$ liters/hour were used during the first $30 \mathrm{~min}$ to allow rapid establishment of anaerobic conditions; the $\mathrm{O}_{2}$ concentration was $<0.1 \%$ after $5 \mathrm{~min}$. For the $20 \mathrm{C}$ experiments, samples were transferred after 3 days at $2.5 \mathrm{C}$ to a flow system in a $20 \mathrm{C}$ room where they were held until the asparagus reached $20 \mathrm{C}(\approx 2 \mathrm{~h})$. Compressed $\mathrm{N}_{2}$ at $20 \mathrm{C}$ was applied as in the $2.5 \mathrm{C}$ experiments. Samples were then returned to $2.5 \mathrm{C}$ for measurements of $\mathrm{CO}_{2}$ production, sensory, and visual evaluation. Samples held in air for $0,2,4$, or $6 \mathrm{~h}$ at 20 or $2.5 \mathrm{C}$ were used as controls.

Sensory evaluation. Difference tests were conducted to detect whether overall appearance and taste differed among treatments. The duo-trio test was selected to establish differences because of its simplicity and sensitivity (Roessler et al., 1978). A panel of 15 judges (graduate students) were trained under conditions identical to those of the actual test. Appearance quality tests were conducted in individual booths with cool-white fluorescent room lighting, while red light was used during taste quality tests to mask any difference in color or general appearance of the spears. Serving was done using the balanced reference mode, in which both of the samples being compared are used at random as the reference. During appearance tests, judges were asked to detect overall differences between the control and each of the treatments. They were asked to evaluate factors such as color, freshness, and decay. They were also requested to indicate which of these factors were considered in their judgment of overall quality.

Fifteen spears from each of the treatments being compared were trimmed to $12 \mathrm{~cm}$, steamed vertically for $10 \mathrm{~min}$, removed from the steamer, and cooled to room temperature before evaluation. Judges tasted both the tip and the basal portion to evaluate the vegetable as a whole. Judges were asked to detect overall differences between the control and each of the two treatments being compared.

Appearance quality was evaluated 7 and 15 days after the 2.5 and 20C treatments. Taste quality was evaluated 4 days after treatment. Results were analyzed using the expanded statistical tables for duo-trio 1 tailed tests compiled by Roessler et al. (1978). According to those tables, a minimum of 12 or 13 correct judgments should be obtained to establish significance at $P<0.05$ or $P$ $<0.01$, respectively, for differences between two treatments when a 15-judge panel is used.

Visual evaluation. Asparagus spears were evaluated visually 6 days after $\mathrm{N}_{2}$ treatments. Evaluation was conducted by the senior author under normal laboratory conditions. Spears were examined for deterioration such as tissue damage, longitudinal depression, water soaking, or obvious changes in aroma or color. Treatments of $0,2,4$, and $6 \mathrm{~h} \mathrm{~N}_{2}$ at 2.5 or $20 \mathrm{C}$ were evaluated. Additional treatments using 12,24 , and $36 \mathrm{~h} \mathrm{~N}_{2}$ at $2.5 \mathrm{C}$ were also evaluated. Results were subjected to an analysis of variance (ANOVA) to compare among treatments at each temperature as well as to detect differences among treatments at the two different temperatures.

\section{Results}

Effect of anaerobic treatments. Because the overall pattern of $\mathrm{CO}_{2}$ production from spears in all treatments and experiments followed a similar large-scale variation (Fig. 1A), the $\mathrm{CO}_{2}$ production data are presented as percentages of the air control on the same day to emphasize differences among the treatments (Fig. 1B, 2). Although the rise in $\mathrm{CO}_{2}$ production after day 4 and the fall after day 9 could have been produced by infection and/or senescence of the tissue, there was no change in the visual appearance of the spears to indicate that they were diseased or rapidly senescing; i.e., there was no appearance of tissue breakdown, fungal hypha, slime, yellowing, opening of the tip, or flaccidness of the tissue for up to 11 days after treatment (data not shown).

An ANOVA of relative $\mathrm{CO}_{2}$ production rates from asparagus exposed to $20 \mathrm{C}$ for 2,4 , or $6 \mathrm{~h}$ on day 0 during continuous storage at $2.5 \mathrm{C}$ in air showed no significant differences among days or among treatments for 5 days after the treatment (Fig. 1B). During this time there was a slight decline in relative $\mathrm{CO}_{2}$ production for all treatments until a prominent rise occurred, which exceeded the control rate on day 6,8 , and 9 for the 6-, 4-, and 2-h treatments, respectively.

The pattern of $\mathrm{CO}_{2}$ production was different for spears exposed to $\mathrm{N}_{2}$ at $2.5 \mathrm{C}$ (Fig. $2 \mathrm{~A}$ ) than at $20 \mathrm{C}$ (Fig. 2B). The relative rate of $\mathrm{CO}_{2}$ production at $2.5 \mathrm{C}$ was higher for the 2- and 4-h anaerobic exposure than for the 0-h control and lower for the 6-h exposure (Fig. 2A). The relative rates of $\mathrm{CO}_{2}$ production on days 1 to 7 were inversely proportional to the length of the anaerobic treatment. A general decline in $\mathrm{CO}_{2}$ production started on day 7 for the 2-h exposure and on day 9 for the 4 - and 6-h exposures. In contrast, the relative $\mathrm{CO}_{2}$ production rate was higher than the 0 -h control for the first 2 days after all anaerobic treatments at 20C, and the increases 


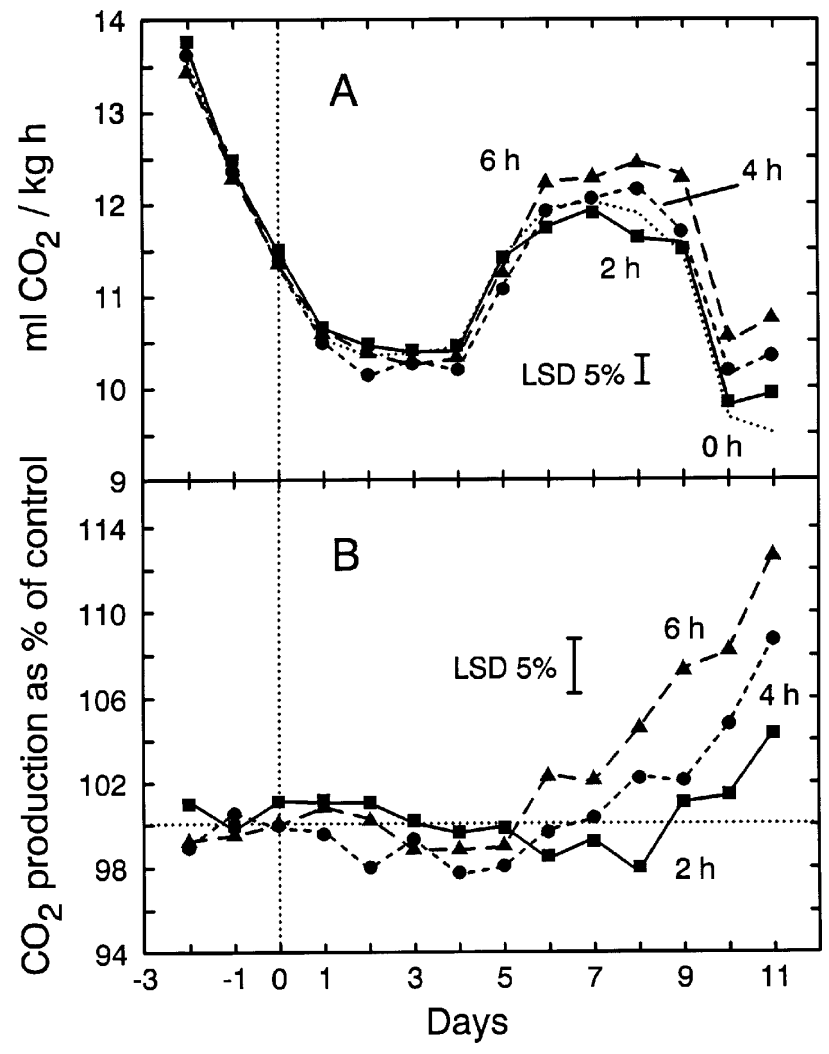

Fig. 1. A. Carbon dioxide production by asparagus spears at $2.5 \mathrm{C}$ before (days -2 to 0 ), and after $0,2,4$, and $6 \mathrm{~h}$ exposure to air at 20C. B. Relative $\mathrm{CO}_{2}$ production by asparagus spears as a percent of the air control at $2.5 \mathrm{C}$ before (days -2 to 0 ) and after $0,2,4$, and $6 \mathrm{~h}$ exposure to air at 20C. Each point is the mean of 3 replicates. The vertical bar represents the calculated 5\% LSD value.

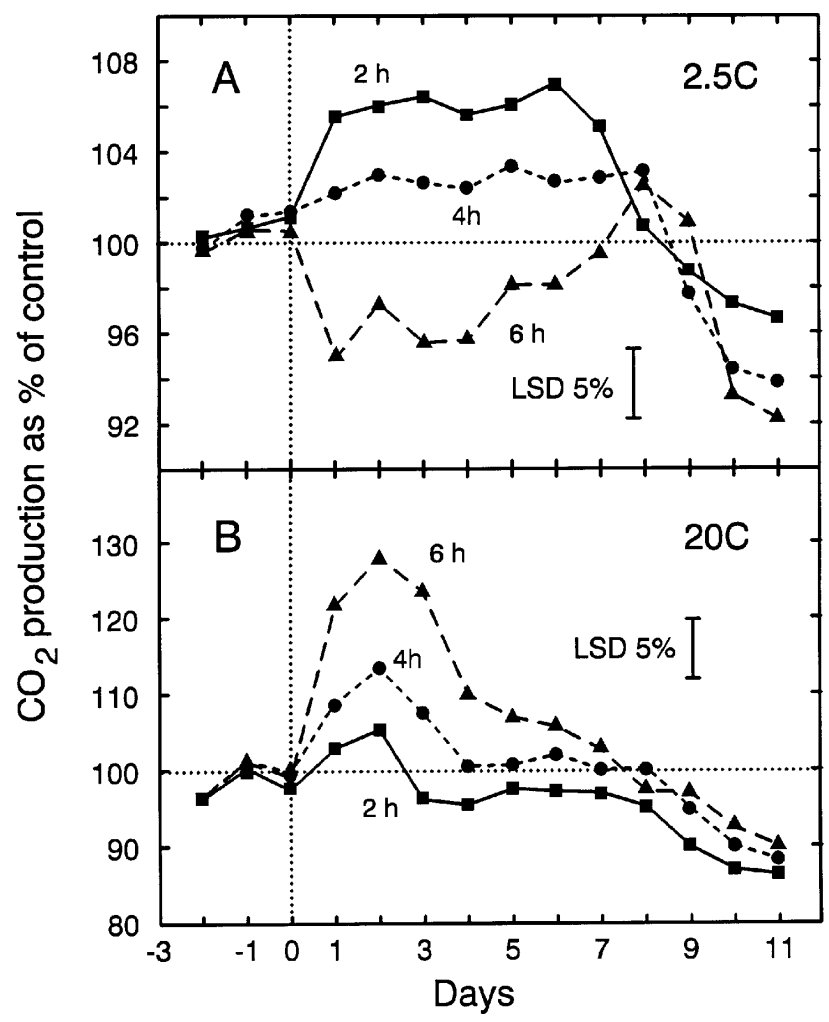

Fig. 2. Carbon dioxide production by asparagus spears as a percent of the air control at $2.5 \mathrm{C}$ before (days -2 to 0 ), and after $0,2,4$, and $6 \mathrm{~h}$ anaerobic $\mathrm{N}_{2}$ treatments at 2.5C (A) and at 20C (B). Each point is the mean of three replicates. The vertical bar represents the calculated $5 \%$ LSD value.
Table 1. Number of correct judgments observed in evaluating anaerobic $\mathrm{N}_{2}$ treatments on the subsequent appearance and taste quality of harvested asparagus spears.

\begin{tabular}{|c|c|c|c|}
\hline \multirow[b]{3}{*}{ Treatment } & \multicolumn{3}{|c|}{ Correct judgments out of 15} \\
\hline & \multicolumn{2}{|c|}{ Appearance } & \multirow{2}{*}{$\frac{\text { Taste }}{\text { After }}$} \\
\hline & $\begin{array}{l}\text { After } \\
7 \text { days }\end{array}$ & $\begin{array}{c}\text { After } \\
15 \text { days }\end{array}$ & \\
\hline $2 \mathrm{~h} \mathrm{~N}_{2}, 2.5 \mathrm{C}$ vs. $0 \mathrm{~h} \mathrm{~N}_{2}, 2.5 \mathrm{C}$ & 7 & 7 & 7 \\
\hline $4 \mathrm{~h} \mathrm{~N}_{2}, 2.5 \mathrm{C}$ vs. $0 \mathrm{~h} \mathrm{~N}_{2}, 2.5 \mathrm{C}$ & 4 & 8 & 8 \\
\hline $6 \mathrm{~h} \mathrm{~N}_{2}, 2.5 \mathrm{C}$ vs. $0 \mathrm{~h} \mathrm{~N}_{2}, 2.5 \mathrm{C}$ & 8 & 6 & 7 \\
\hline $2 \mathrm{~h} \mathrm{~N}_{2}, 20 \mathrm{C}$ vs. $0 \mathrm{~h} \mathrm{~N}_{2}, 2.5 \mathrm{C}$ & 6 & 6 & 8 \\
\hline $2 \mathrm{~h} \mathrm{~N}_{2}, 20 \mathrm{C}$ vs. $2 \mathrm{~h}$ air, $20 \mathrm{C}$ & 4 & 11 & 8 \\
\hline $4 \mathrm{~h} \mathrm{~N}_{2}, 20 \mathrm{C}$ vs. $0 \mathrm{~h} \mathrm{~N}_{2}, 2.5 \mathrm{C}$ & 9 & 10 & 10 \\
\hline $4 \mathrm{~h} \mathrm{~N}_{2}, 20 \mathrm{C}$ vs. $4 \mathrm{~h}$ air, $20 \mathrm{C}$ & 6 & 11 & 10 \\
\hline $6 \mathrm{~h} \mathrm{~N}_{2}, 20 \mathrm{C}$ vs. $0 \mathrm{~h} \mathrm{~N}{ }_{2}, 2.5 \mathrm{C}$ & 8 & 10 & 11 \\
\hline $6 \mathrm{~h} \mathrm{~N}_{2}, 20 \mathrm{C}$ vs. $6 \mathrm{~h}$ air, $20 \mathrm{C}$ & 11 & 8 & 10 \\
\hline
\end{tabular}

Table 2. Analysis of variance of a comparison among subjective evaluation of appearance and taste quality 6 days after treatments $(n=3)$.

\begin{tabular}{lc}
\hline \hline Treatments & F value \\
\hline $2.5 \mathrm{C}$ & \\
$0 \mathrm{~h}$ vs. $2 \mathrm{~h}$ vs. $4 \mathrm{~h}$ vs. $6 \mathrm{~h} \mathrm{~N}_{2}$ & $0.237^{\mathrm{Ns}}$ \\
$12 \mathrm{~h}$ vs. $24 \mathrm{~h}$ vs. $36 \mathrm{~h} \mathrm{~N}_{2}$ & $0.459^{\mathrm{Ns}}$ \\
$0,2,4$, and $6 \mathrm{~h} \mathrm{~N}_{2}$ vs. & \\
$\quad \begin{array}{l}12,24 \text {, and } 36 \mathrm{~h} \mathrm{~N}_{2} \\
\text { 20C }\end{array}$ & $1.279^{\mathrm{Ns}}$ \\
$0,2,4$, and $6 \mathrm{~h} \mathrm{~N}_{2}$ vs. & \\
2,4 , and $6 \mathrm{~h}$ air & $1.192^{\mathrm{Ns}}$
\end{tabular}

${ }^{\mathrm{NS}}$ Nonsignificant at $P=0.05$.

were directly proportional to the length of exposure (Fig. 2B). The maximum relative rate of $\mathrm{CO}_{2}$ production was also much more pronounced from spears exposed to anaerobiosis at 20C (Fig. 2B) than at $2.5 \mathrm{C}$ (Fig. 2A). The increased response was possibly because both a temperature and an anaerobic stress were involved. After day 2, there was a general decline in the relative rate of $\mathrm{CO}_{2}$ production for all $20 \mathrm{C}$ anaerobic treatments with the rate reaching the 0 -h control levels on day 3, 4, and 8 for the 2-, 4-, and 6-h exposures, respectively. After day 8 , there was a rapid and parallel decrease in relative $\mathrm{CO}_{2}$ production from spears exposed to all anaerobic treatments. This decline was less pronounced for spears exposed at 2.5C (Fig. 2A) than at 20C (Fig. 2B).

Sensory evaluation. Appearance quality tests did not reveal any significant differences among the controls and any of the anaerobic treatments at 2.5 or $20 \mathrm{C}$, after either 7 or 15 days (Table 1 ). The number of correct judgments was below the minimum 12 and 13 needed for confidence levels of $5 \%$ and $1 \%$, respectively (Roessler et al., 1978). Taste quality tests conducted 4 days after the treatments also showed that judges could not distinguish between any of the anaerobic and control treatments. Appearance and taste quality tests showed that judges could not distinguish among the 2,4 , and 6-h $\mathrm{N}_{2}$ exposures at $2.5 \mathrm{C}$, among the 12-, 24-, and 36-h $\mathrm{N}_{2}$ exposures at $2.5 \mathrm{C}$, between the short term $(0,2,4$, and $6 \mathrm{~h})$ and long term $(12,24$, and $36 \mathrm{~h}) \mathrm{N}_{2}$ exposures at $2.5 \mathrm{C}$, or between the $\mathrm{N}_{2}$ exposures $(2,4$, and $6 \mathrm{~h})$ and the air exposures $(2,4$, and $6 \mathrm{~h})$ at 20C (Table 2).

Visual evaluation. An ANOVA comparing the percentage of decayed asparagus spears 6 days after the 2-, 4-, or 6-h $\mathrm{N}_{2}$ treatments at 2.5 or $20 \mathrm{C}$ showed no significant difference among 
Table 3. Analysis of variance for a comparison of subjective evaluations of deterioration such as tissue damage, longitudinal depression, water soaking or obvious changes in aroma or color which occurred after 6 days between treatments of $0,2,4$, and $6 \mathrm{~h} \mathrm{~N}_{2}$ and temperatures of 2.5 and $20 \mathrm{C}$.

\begin{tabular}{lcrr}
\hline \hline Source & df & \multicolumn{1}{c}{ MS } & F value \\
\hline Replicate & 2 & 22.54 & $0.21^{\text {Ns }}$ \\
Temperature & 1 & 2185.04 & $20.60^{* *}$ \\
Treatment & 3 & 39.93 & $0.38^{\text {NS }}$ \\
Temperature $\times$ Treatment & 3 & 24.15 & $0.23^{\text {NS }}$ \\
\hline
\end{tabular}

Ns, $* *$ Nonsignificant or significant at $P<0.01$.

any of the treatments (Table 3 ). Comparison between the $0,2,4$, and $6 \mathrm{~h} \mathrm{~N}$ treatments at $2.5 \mathrm{C}$ and the treatments at $20 \mathrm{C}$ showed no significant difference among treatments; however, there was a significant difference $(P<0.01)$ between temperatures.

\section{Discussion}

Even though there were some significant treatment effects on $\mathrm{CO}_{2}$ production by the anaerobic exposures of 2 to $6 \mathrm{~h}$ (Fig. 2), such significant effects did not extend to the sensory quality of spears as determined by judges in the formal sensory panel or by subjective evaluation (Tables 1 and 2). Subjective evaluation after 6 days also showed that no significant differences existed in the number of unacceptable asparagus spears among temperatures even when longer anaerobic treatments were used (Table 3).

Although low- $\mathrm{O}_{2}$ atmospheres are known to decrease the respiration of harvested asparagus (Lipton, 1990), the effects of shortterm exposures to anaerobic atmospheres have not been reported. The peak in relative $\mathrm{CO}_{2}$ production on day 2 for spears exposed to $\mathrm{N}_{2}$ at 20C (Fig. 2B) was in stark contrast to the flat response of spears exposed to air at 20C (Fig. 1B). It is evident that the differences in response indicate that subsequent $\mathrm{CO}_{2}$ production is more a consequence of the short anaerobic stress than of exposure to $20 \mathrm{C}$.

The physiological cause for the stimulation and later decline in relative $\mathrm{CO}_{2}$ production by spears exposed to anaerobic atmospheres for 2,4 , and $6 \mathrm{~h}$ at $20 \mathrm{C}$ and for 2 and $4 \mathrm{~h}$ at 2.5 is unknown, but the possibility exists that accumulated products of anaerobic respiration may be responsible. Production of $\mathrm{CO}_{2}$ by tomato fruit is stimulated by continuous exposure to ethanol vapors (M.E. Saltveit, unpublished data), and respiration is subsequently depressed when ethanol-treated tomato fruit are returned to air (Saltveit, 1989). Residual effects of low $\mathrm{O}_{2}$ atmospheres on reducing respiration have also been noted for other commodities (Ke et al., 1990).

Platenius (1943) showed that during a 3-day period, the rate of $\mathrm{CO}_{2}$ production from asparagus decreased $60 \%$ in a $2.3 \% \mathrm{O}_{2}$ atmosphere compared to air. Anaerobic respiration developed below that critical $\mathrm{O}_{2}$ level, as shown by an increase in $\mathrm{CO}_{2}$ production. Under our experimental conditions, a decrease in $\mathrm{CO}_{2}$ production with respect to the air control was found 8 days after the anaerobic treatments (Fig. 2).

Since exposure to anaerobic atmospheres for up to $6 \mathrm{~h}$ at 2.5 to 20C did not significantly reduce subsequent asparagus quality, these anaerobic treatments may have a beneficial effect on the appearance of asparagus. Ke and Kader (1989) mentioned that, besides subsequent inhibition of respiration in a number of crops, exposure to low $\mathrm{O}_{2}$ atmospheres also inhibits ethylene production, color development and softening, as well as control of some physiological disorders, decay, and insects. Lipton (1957, 1968) reported that an informal taste panel preferred stored asparagus over fresh spears. When analyzing flavor of $30 \% \mathrm{CO}_{2}$-treated asparagus, half of the people preferred spears held in air and half preferred those held in $\mathrm{CO}_{2}$. Lipton (1965) also found that an atmosphere of $1 \% \mathrm{O}_{2}$ for 7 days at $6 \mathrm{C}$ reduced soft rot, while it was eliminated by $0 \% \mathrm{O}_{2}$, but that this low- $\mathrm{O}_{2}$ atmosphere caused some low- $\mathrm{O}_{2}$ injury to the spears. Reduced decay has also been observed in strawberries under low- $\mathrm{O}_{2}$ atmospheres, especially at $0.25 \% \mathrm{O}_{2}$ (Ke et al., 1991).

Detrimental effects of anaerobic atmospheres include the accumulation of ethanol and acetaldehyde to levels that caused offflavors, and an enhancement of some physiological disorders (Ke and Kader, 1989). Saltveit and Ballinger (1983a, b) found that ethanol concentrations increased linearly with up to $4 \mathrm{~h}$ under $\mathrm{N}_{2}$ or $\mathrm{CO}_{2}$ atmospheres and exponentially with temperatures from 0 to 30C. A 6-h anaerobic exposure at 2.5 or $20 \mathrm{C}$ apparently did not induce sufficient anaerobic metabolism to significantly affect subsequent quality (Tables 1,2 , and 3 ).

According to results obtained from these experiments, no significant effects of anaerobic respiration were detected on quality when $\mathrm{O}_{2}$ levels below $0.1 \%$ were established for up to $6 \mathrm{~h}$ under $\mathrm{N}_{2}$ atmospheres at 2.5 or $20 \mathrm{C}$. For that reason, cooling asparagus with volatilized liquid $\mathrm{N}_{2}$, during which an anaerobic atmosphere may be produced before the spears were significantly cooled, could be used without affecting subsequent appearance or taste.

\section{Literature Cited}

Baxter, L. and L. Waters. 1991. Quality changes in asparagus spears stored in a flow-through CA system or in consumer packages. HortScience 26:399-402.

Clore, W.J., G.H. Carter, and S.R. Drake. 1976. Pre- and postharvest factors affecting textural quality of fresh asparagus. J. Amer. Soc. Hort. Sci. 101:576-578

Gariepy, Y., G.S.V. Raghavan, F. Castaigne, J. Arul, and C. Willemot. 1991. Precooling and modified atmosphere storage of green asparagus. J. Food Processing and Preservation 15:215-224.

Ke, D. and A.A. Kader. 1989. Tolerance and response of fresh fruits to low $\mathrm{O}_{2}$ levels at or below 1\%. Proc. of Fifth Intl. Conf. on Controlled Atmospheres. vol.2. Wenatchee, Wash. 209-216.

Ke, D., H. Gorsel, and A.A. Kader. 1990. Physiological and quality responses of 'Bartlett' pears to reduced $\mathrm{O}_{2}$ and enhanced $\mathrm{CO}_{2}$ levels and storage temperature. J. Amer. Soc. Hort. Sci. 115:435-439.

Ke, D., L. Goldstein, M. O'Mahoney, and A.A. Kader. 1991. Effects of short-term exposure to low $\mathrm{O}_{2}$ and high $\mathrm{CO}_{2}$ atmospheres on quality attributes of strawberries. J. Food Sci. 56:50-54.

King, G.A., K.G. Henderson, and R.E. Lill. 1988a. Shelf life of stored asparagus is strongly related to post-harvest accumulated heat units. Ann. Applied Biol. 112:329-335.

King, G.A., K.G. Henderson, E.M. O'Donoghue, W. Martin, and R. Lill. 1988b. Flavor and metabolic changes in asparagus during storage. Scientia Hort. 36:183-190.

Lill, R.E. 1980. Storage of fresh asparagus. N.Z. J. Expt. Agr. 8:163-167. Lipton, W. 1957. Physiological changes in harvested asparagus (Asparagus officinalis) as related to temperature of holding. $\mathrm{PhD}$ Thesis, Univ. of California, Davis.

Lipton, W. 1965. Postharvest responses of asparagus spears to high $\mathrm{CO}_{2}$ and low $\mathrm{O}_{2}$ atmospheres. Proc. Amer. Soc. Hort. Sci. 86:347-356.

Lipton, W. 1968. Marketing quality of asparagus: Effects of maturity at harvest and of high $\mathrm{CO}_{2}$ atmospheres during simulated transit. U.S. Dept. Agr. Marketing Res. Rpt. 817.

Lipton, W. 1990. Postharvest biology of fresh asparagus. Hort. Rev. 12:69-155.

Lutz, J.M. 1938. Evaluating quality changes in certain vegetables after harvesting. Proc. Amer. Soc. Hort. Sci. 36:755-759.

Pentzer, W.T., R.L. Perry, G.C. Hanna, J.S. Wiant, and C.E. Asbury. 1936. Precooling and shipping California asparagus. Univ. Calif. Agr. 
Expt. Sta. Bul. 600.

Platenius, H. 1942. Effect of temperature on the respiration and the respiratory quotient of some vegetables. Plant Physiol. 17:179-197.

Platenius, H. 1943. Effect of $\mathrm{O}_{2}$ concentration on the respiration of some vegetables. Plant Physiol. 18:671-684.

Roessler, E.B., R.M. Pangborn, J.L. Sidel, and H. Stone. 1978. Expanded statistical tables for estimating significance in paired-preference, paireddifference, duo-trio and triangle test. J. Food Sci. 43:940-947.

Saltveit, M.E. 1989. Effect of alcohols and their interaction with ethylene on the ripening of epidermal pericarp discs of tomato tissue. Plant Physiol. 90:187-174.

Saltveit, M.E. and W.E. Ballinger. 1983a. Effects of anaerobic nitrogen and carbon dioxide atmospheres on ethanol production and postharvest quality of blueberries. J. Amer. Soc. Hort. Sci. 108:459-462.

Saltveit, M.E. and W.E. Ballinger. 1983b. Effects of anaerobic nitrogen and carbon dioxide atmospheres on ethanol production and postharvest quality of 'Carlos' grapes. J. Amer. Soc. Hort. Sci. 108:462-465.

Saltveit, M.E. and R.F. Kasmire. 1985. Changes in respiration and composition of different length of asparagus spears during storage. HortScience 20:1114-1116.

Saltveit, M.E. and T. Strike. 1989. A rapid method for accurately measuring oxygen concentrations in ml gas samples. HortScience 24:145-147.

Scott, L.E. and A. Kramer. 1949. Physiological changes in asparagus after harvest. Proc. Amer. Soc. Hort. Sci. 54:357-366.

Sharma, S.C. and R.R. Wolfe. 1976. Mathematical modeling of the postharvest textural behavior of asparagus. Trans. Amer. Soc. Agr. Eng. 19:984-988.

U.S. Dept. of Agriculture, Agricultural Marketing Services. 1972. Asparagus: shipping point and market inspection instructions. Washington, D.C. 